\title{
TOMAS LOPEZ'S GEOGRAPHIC ATLAS OF SPAIN IN THE PENINSULAR WAR: A METHODOLOGY FOR DETERMINING ERRORS
}

\author{
C. San-Antonio-Gómez ${ }^{1}$, C. Velilla ${ }^{1}$ and F. Manzano-Agugliaro ${ }^{2}$ \\ ${ }^{1}$ Universidad Politécnica de Madrid-UPM \\ ${ }^{2}$ Universidad de Almeria
}

\begin{abstract}
During the Peninsular War, Napoleon's and Wellington's armies were aware of the lack of precision in the maps of Spain and its provinces that appeared in Tomas Lopez's Geographical Atlas of Spain. The errors were due to the non-topographical surveying method he used, which he had learned from his teacher Jean Baptiste Bourguignon D'Awwille. To map all of the Spanish provinces, Tomas Lopez divided them into circles of three leagues in diameter $(16,718 \mathrm{~m})$, taking a particular town as the centre. He asked the town's priest to draw a map of the territory and to complete a questionnaire that Tomas Lopez sent to him. The priest was to return the two documents after he had completed them. Subsequently, at his desk, Tomas Lopez used the maps and reports as well as other graphic and written sources from various locations to make an outline of each map. Next, he made a mosaic that served as a pattern for drawing the final provincial map. We will see the way that this method was applied in two concrete cases: the villages of Chavaler and Monteagudo, situated in the Spanish province of Soria, and verify their degree of accuracy. We will use the maps drawn by the priests in 1767, the final map of the province which was published in 1804 by Tomás Lopez, and a current map of the province showing the angular and linear errors in Lopez's map.
\end{abstract}

KEYWORDS: Tomas Lopez. Accuracy. Historical Cartography. Peninsular war.

\section{INTRODUCTION}

In the mid-18th century, trigonometric and geodetic methods were already known. Their principles were given by Gemma Frisius (1508-1555) in 1533 [16]. Geodetic references on which to base topographic surveys began to appear, such as the one made by Willebrord Snellius (1580-1626), who made the first precise triangulation in 1617 when he measured an arc between Bergen op Zoom and Alkmaar, with a base close to Leyden, and the one made by Picard (1620-1683) in 1670 of the Paris meridian between Malvoisine and Sourdon [20]. These methods, however, required technical and personal means that were scarce those days. Furthermore, the Illustration's encyclopaedic ambition encouraged the European monarchies to map their territories and to promote geographic dictionaries, which meant that topographic surveys had to be made of the remotest locations. Due to the lack of funding, personnel, and the technical means to carry out the surveys, cartographers sought the assistance of monks, priests, soldiers and tax collectors with sufficient graphic knowledge to draw a map intuitively. In Spain, such surveys were widespread and led to "Desk Cartography" made by expert cartographers. They were based on very unreliable fieldwork carried out by village priests, so the maps are not very precise. Alinhac has called this elementary method as Ecclesiastic Topography [1].

In Spain, the promoter of such methods was Tomas Lopez (1730-1802), who was a student of Jean Baptiste Bourguignon d'Anville (1697-1782), one of the $18^{\text {th }}$ century's most prestigious cartographers. In part, D'Anville applied the method of François Chevalier, whose student he was [1] and which is considered to be the best example of Desk Cartography. Tomas Lopez studied the Desk Cartography during his nine years stay in Paris. 
Nonetheless, the methods used by Chevalier and Lopez have one thing common that the field work used to draw the maps was carried out by village priests who followed their instructions. Chevalier's method was ingenious and more rigor because it gave precise indications on how to position a map, set distances and define the symbols for graphic representation [4]. On the contrary, Lopez left such issues to the village priests' discretion. He was more concerned with making an inventory of the location by sending out a questionnaire called Interrogatorio which the priests were to complete and return to him, together with the map they had drawn. Originally, the method was designed for making the Diccionario Geografico-Historico de España (Geographical and Historical Dictionary of Spain), an unfinished project promoted by the Spanish Royal Academy of History in 1776 [10]. That was why he asked the village priests for a map of the location and complete information on statistics and geography of the region. Tomás López used all of the material which he gathered to prepare the Atlas Geográfico de España (Geographical Atlas of Spain), a posthumous work published by his sons in 1804 [11].

The aim of this paper is to review the cartographic method used by Tomas Lopez and define a methodology for studying its reliability, in order to discover the origin of errors he made in the maps in the Atlas Geográfico de España, due to his way of drawing from such unscientific and disconnected sources. The lack of accuracy in his maps, inherent to his non-surveying methods, was verified by Wellington during his campaigns against Napoleon in the 1809-1814 Peninsular War and by French General Staff, whose engineers had to correct the cartography for their areas of military interest [13], as shall be seen.

Since Lopez's non-surveying methods were so inexact, it is impossible to determine a similar error for each provincial map in his Atlas Geográfico de España. Lopez's maps were made by adding his sketches, which in turn were based on the sketches each village priest had made of his area and sent to Lopez. Therefore, the errors for each one of those areas would have to be detected before the mean error for a provincial map could be determined. In this paper, we define and apply a methodology that enables us to determine the errors in two samples, the maps of the areas that includes the villages of Chavaler and Monteagudo and its regions, which belongs to Soria province. The documents studied are: the sketchs of Chavaler and Monteagudo that the village priests made in year 1767 and the final map of Soria province that Lopez drew from all of the sketches and published for the first time in year 1783 (all of the other provincial maps were included in the Atlas Geográfico de España in year 1804); and the current map of Soria province. Thus we have studied the metric aspects of Lopez's method in order to point out his linear, angular and distances errors by comparing historical data with current data.

\section{Maps of Spain at the Beginning of the Pentnsular War}

Maps of Spain at the beginning of the Peninsular War were few and unreliable. Therefore, Napoleon arranged that, given:

"the lack of topographic material on Spain, it is an important duty of the geographical engineers at the Army's Topographic Office (French, in Spain), to collect with all due diligence and utmost care anything that may exist in public depots, in the War Depot and the Navy Depot in Madrid, the files of scientific societies, provincial universities, and the church. Equal attention is to be paid to collecting astronomic and trigonometric results... "[2].

All the above material was to be collected at the Spanish Army's Topography Office, which was created in Bayonne on 27 February 1808. The following year, on 30 
November 1809 , Jose Bonaparte created a General Depot for Geographical Charts of Plans and Topographical Sketches.

The best-known maps of Spain were the ones which were engraved in the $18^{\text {th }}$ century, such as the one published in Paris: Hispania (1725), by Guill de L'Isle, included in the Atlas Novus. Some of the maps engraved in London were: A map of the Kingdoms of Spain and Portugal (1745) by Tendal, engraved by R. W. Seale; and $A$ map of the Kingdoms of Spain \& Portugal (1794), by Sculp. T. Conder, published by R. Wilkinson. Among the maps published in Spain, we can refer the Mapa de las carreteras de postas de España (1760) by Ricardo Vall and the one made by Jesuits Martinez and de la Vega (1739-1743). They are all general maps of Spain and, therefore, they are not very precise.

When the war commenced, the most current maps of Spain were the ones in the above-mentioned Atlas Geográfico de España by Tomas Lopez, which was published in 1804, shortly before Napoleon invaded Spain. The map was reprinted in 1810 , during the war. The Atlas contained 38 maps divided into 102 pages and with different scales for each map, which varied between 1:140,000 and 1:640,000.

Tomas Lopez's maps were used by Wellington's army for their military operations [5]. However, the British soon realized how imprecise they were. Theirs was a much smaller expeditionary force than the French army, so they needed reliable maps that would give them a strategic advantage. Therefore, they decided to carry out their own topographical surveys to draw their own maps [17].

The outcome was the publication of several maps of the Iberian Peninsula. One outstanding work is War in the Peninsula, which was made under the orders of Colonel Murray. Several English officials were known for their surveying work: Bainbrigge, Mitchell, Freeth, Pierrepoint and Colleton were well taught at the Ordnance Survey School, where they made precise surveys that were far superior to any previous ones. Accordingly, the Duke of Wellington based some of his most important movements on them during the Peninsular War [14].

The Peninsular War campaigns marked an extraordinary stage in the development of British military cartography. A new way of organizing topographic surveys, in which army officials and experts in geodetic and cartographic work took part, replaced the one used prior to the Napoleonic Wars. Furthermore, in 1808, lithography was used for the first time to print maps.

The cartography made by the French army includes a Mapa de España y Portugal (Map of Spain and Portugal), at a 1:500.000 scale, comprising 12 large sheets, which were made for Napoleon. It was begun in July 1808 and was drawn in six weeks. The basic information was obtained from Tomas Lopez's maps [14] and Tofiño's charts, to which communications based on the 1785 Mentelle map, were added and which appeared in l'Etat des Postes de Bourgoin. Many topographical surveys of itineraries, areas of military importance and garrisons were made

\section{Precedents of Tomas Lopez’s Cartographic Method}

As an ancient precedent, we have Las relaciones topográficas de Castilla y Geográficas de Indias, by King Philip II of Spain. In the year 1575, a questionnaire containing 57 items was sent to every town under the Crown of Castile to collect the wanted information. Two years later, a new questionnaire with 49 items was sent to America, to the viceroyalties of New Spain (Mexico) and Peru.

Each questionnaire was accompanied by a sketch of the area. The outcome is the most extraordinary collection of maps of enclaves, towns and cities of America in the $16^{\text {th }}$ century. The other big questionnaire made in Spain took place in the $18^{\text {th }}$ century 
for the Catastro (Cadastral Survey) ordered by the Marquis of Ensenada, which also produced extraordinary samples of basic surveys purely for tax purposes.

The bibliography on Tomas Lopez is exhaustive, particularly after the bicentenary of his death in year 2002. Two facsimile editions of his Atlas Geográfico de España have been published, one in 1992 [19], and the other in 2005 [6]. Among the authors in Spain who have studied the life and works of Tomas Lopez, we find C. Liter Mayayo who published many books on history, the most important of which was a bibliographic collection of all of his maps [9]. A. Lopez Gomez has also published several works, of which we refer the most recent one [10]. The book by J. A. Saez Garcia [18] is also worthy of mention, although its content is strictly historical, as found in most of the studies by Lopez. Outside of Spain, A. F. Buschings, [3] and B. H. Vayssière [21] have also studied the works of Tomas Lopez from a historical perspective.

Further information on the usage made and the errors discovered of the maps in Tomas Lopez's Atlas Geográfico de España by the armies of Wellington and Napoleon during the Peninsular War, are available in other works [13] and [17].

\section{The Cartographic Method used by Tomas Lopez: the Questionnaire}

The questionnaire consisted of collecting and ordering pre-extant information and information gathered for the occasion, to be used to make maps. The maps made during the $16^{\text {th }}, 17^{\text {th }}$ and $18^{\text {th }}$ centuries were one of such sources, together with vast quantities of documents (i.e., answers to questionnaires, local histories, geographical descriptions, and cartographic sketches), which have been preserved in Spain's National Library.

Lopez achieved valuable work, particularly in the perfection of engravings and the printed quality of maps, as in case of the Atlas Geográfico de España, the first comprehensive and detailed map of Spain. Although he never did any fieldwork, Lopez was aware of the latest advances in scientific cartography and acknowledged that:

the best way to make a map is by walking and measuring the land, but such method is not possible for a private individual [8].

In other words, for a mere geographer such as himself, who had neither the equipment, nor the material or the personnel that such a method required. In his work Principios geográficos aplicados al uso de los mapas (Geographical Principles Applied to the Usage of Maps), published in 1775, Lopez explains how he did cartography:

"A geographer works at home, with several documents of a single piece of

land laid out before him, which he compares and adapts as he considers best.

It is not for him to do surveying, for others do that sort of work... If

geographers needed to see and measure the land represented on their maps,

not one of them would have been able to publish even one of the four parts of

the Earth during his lifetime; and yet that is what they do" [9].

Towards 1766, in view of the difficulties he encountered in making maps of Spain's provinces, Tomas Lopez, authorised by the appropriate minister, officially addressed a 15 items questionnaire, or "Interrogatorio" to bishops, village priests and civil servants, asking them for data on their dioceses and parishes.

\section{The method used for the Interrogatorio}

In the Interrogatorio was recommended that the priest should take their village or town as the centre of a circle with a radius of three leagues, to focus on the land 
within that circle. The information requested was mainly statistical, i.e.: the name of the hamlets, villages and towns and the distance between them in Spanish leagues, with an indication of their orientation; the name of the rivers, brooks and lagoons, and their bridges; the names of mountain ranges and the name of their passes and woods.

The Interrogatorio is preserved in Madrid, at the Spanish National Library, and it is reproduced literally in several publications [7].

Tomas Lopez also requested a small map of the territory within a three league radius, which was to include all the above information. Tomas Lopez told the priests that although:

"it was not done like a professor would do it, we shall be content with a mere idea or sketch of the land, for we shall fix it by giving it a finishing touch. We are aware that many of you are amateur geographers and each one of you is very capable of showing us what lies within your villages and in the surrounding area." [15].

Some of the maps which were sent are very beautiful in content, whereas others are unintelligible. Soon, Tomas Lopez began to receive the responses to the Interrogatorio. He verified that they had been completed and then filed them. The Interrogatorio contained two types of information: one on statistics, and the other on the geographic data provided by some of the questions and, above all, by the maps sent by the parish priests.

The geographic information was used to make the maps that were published annually and that were collected to make the Atlas Geográfico de España. Tomas Lopez used the diagrams of the regions that made up each province and previous maps from several different locations. He performed very detailed desk work, and then fitted everything together conveniently and carefully to make a draft copy or basic document with which to engrave a copper plate that would then used to reproduce a provincial map.

This was an arduous task that not always obtained results because, as Vayssière said:

"he died, exhausted, in 1802, after trying in vain to coordinate hundreds of maps that were inconsistent with each other" [21].

There is no evidence that Lopez submitted the answers to his Interrogatorio to critical examination. There are no annotations and observations written on them, as opposed to his teacher D'Anville, who did compare and confront the reports he received.

Lopez found the Interrogatorio was very useful, since it provided him with sketches that he could use to draw many locations at the right places, according to their relative situation, which had not been mapped before. However, none of the data was of scientific value because the authors lacked the appropriate learning.

It is surprising that in his Interrogatorio Tomas Lopez, having been D'Anville's pupil, failed to take into account $M$. Chevalier's proposal to standardize the data he received from the priests. Chevalier, D'Anville's teacher, designed a more scientific method for standardizing the questionnaires, called the Method of Ecclesiastic Topography [12].

\section{The Methodology Applied: the Map of Soria Province}

Of the 38 provincial maps contained in the Atlas Geográfico de España, we selected the one called Geographic Map of Soria Province (Figure 1) with which to study Tomas Lopez's cartographic method. Lopez published it for the first time in 1783 (it was included in the Atlas Geográfico de España in 1804). 
The map has graded margins. In the upper margin appears "Eastern Longitude from Madrid" and in the lower margin appears "Eastern longitude from Teide Peak of Tenerife Island". The lower right corner shows a list of symbols and the graphic scale, which is given in three ways:

- "6 Leagues out of 20 of the so-called Marine Degree and also of one hour of walking, each one contains 6626 Spanish varas" (A vara is a unit of measurement approximately equivalent to one yard).

- "5 Spanish Geographic Leagues, of which $17^{1 / 2}$ fit into one degree: each one is the equivalent of 7572 Spanish varas".

- "8 legal leagues of 5,000 varas each of which $26^{1 / 2}$ fit into one degree".

The relief is drawn within projected shaded outline. The hydrography and wooded areas are shown and the toponymy is abundant. In the lower left corner, there is a cartouche with the title, and in the upper left corner there appears a list of the source documents used to make the map. It is a long list that gives us an idea of how complex it was to integrate all that material to make a mosaic of the map, which explains why it has errors. In all, the map contains 58 references, of which 41 are mapped by village priests, and nine are written lists of areas of which the priests were unable or unwilling to make a map. The other eight are documents of various types: 2 lists of cities, towns, locations, farms and uninhabited parts of the province, distinguishing the ones in each jurisdiction; and one cartouche with the distances of some towns and locations, both of which were provided by the province's quartermaster general. The bishop provided Lopez with four manuscript maps belonging to the dioceses, as well as a letter for each priest. There was also another map from a private individual.

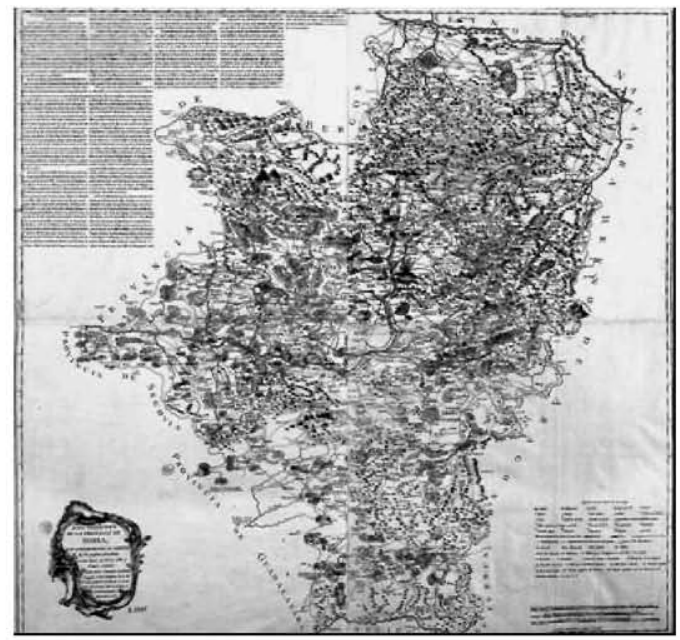

Fig. 1. Geographical Map of Soria Province. Tomas López (1783). Biblioteca Nacional, Madrid (Spain) Ref. GM/ M.II (Original measurements: $84 \times 86 \mathrm{~cm}$.)

The analyzed maps: the villages of Chavaler and Monteagudo

The first map studied was one drew in 1767 by the priest of Portelrubio, Manuel Diez, which represents the town of Chavaler and its region (Map A-1) (Figure 2.) (Biblioteca Nacional de España, Mss. 7307.-fol.97-98). At his desk, Tomas Lopez used the map to draw an outline or sketch (Map B) (Figure 3). He unified each one of the maps sent to him by the priests in this fashion, the better to integrate them. He then used the sketches and other graphic and written sources to draw the map of the 
province. The fragment that corresponds to Chavaler and its region in this map is Map C-1 (Figure 4).

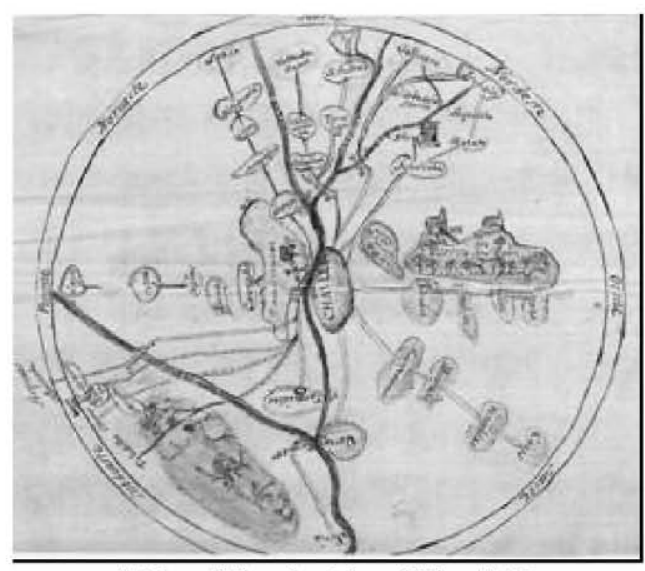

1) Map of Chavaler, Manuel Diaz (1767)

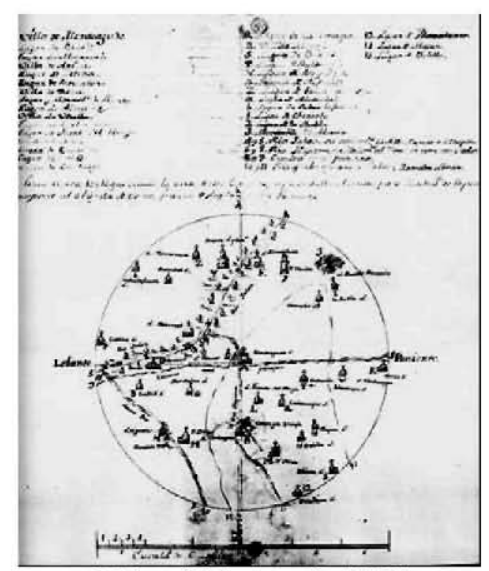

2) Map of Monteagudo (1767)

Fig. 2. Maps A (Biblioteca Nacional).

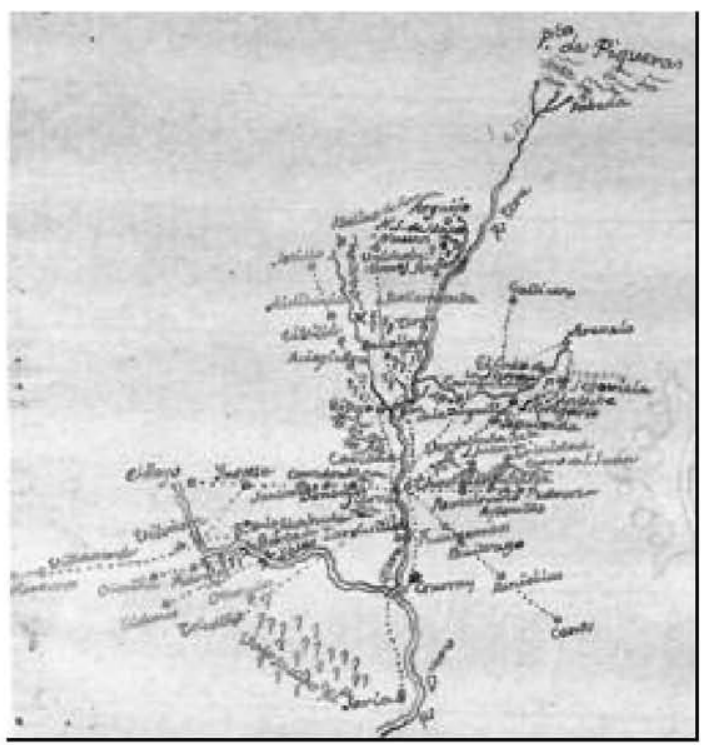

Fig. 3. Map B: Sketch of Chavaler by Tomas Lopez. Biblioteca Nacional.

Although the errors are evident, as we shall see, quite a lot of skill was also employed: the map shows the Duero River correctly drawn for the first time, upstream from Soria city, with its course turning to the left at the level of the town of Garray. In previous maps, the river's course was represented at that point with a curve to the right.

The second studied map was drew by the priest of Monteagudo, which represents the town of Chavaler and its region (Map A-2) (Figure 2.) (Biblioteca Nacional de España, Mss. 7307.-fol.177-180). From this map, and with the same procedure as the previous one, Lopez drew the share of the map of the province (Map C-2) (Figure 4). 


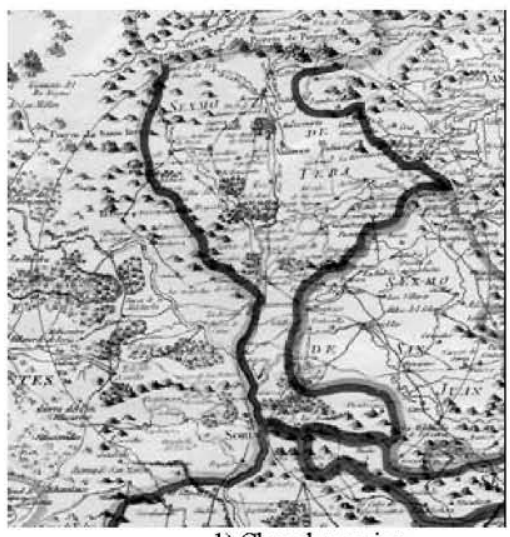

1) Chavaler region



2) Monteagudo region

Fig. 4. Maps C: Fragments of the Geographic Map of Soria Province by Tomas Lopez (1783). Biblioteca Nacional.

\section{Methodology Used to Discover the ERRORS}

Our intention is to devise a methodology to discover the angular and linear errors of the maps of these regions and that could be extended to any other area. The cartographic documents used for a precise study of Lopez's method are listed below:

- Map A-1 of Chavaler, which shows a surface equal to a circle with a radius of three Spanish leagues and the town of Chavaler in the centre.

- Map C-1, on which a circumference with a radius of $16.72 \mathrm{~km}$ is drawn, the equivalent of three Spanish leagues and with Chavaler in the centre, to outline the same surface as in Map A.

- Map A-2 of Monteagudo, which shows a surface equal to a circle with a radius of three Spanish leagues and the town of Monteagudo in the centre.

- Map C-2, on which the same circumference is drawn, with Monteagudo in the centre, to outline the same surface as in Map D.

- The sheets of the MTN (Topographic National Map, which is currently the official map of Spain, made by the IGN - Instituto Geográfico Nacional- at scale 1:50,000) for both studied regions. These sheets were used as a benchmark to assess the precision of Maps A and $\mathrm{C}$.

Map B, which corresponds to the one sketched by Tomas Lopez, was not used because it had no scale for reference and because it was considered to be a mere transcription of Map A.

\section{Digitisation of maps $A$ and $C$}

To digitise the maps, each one had to be geo-referenced, using the MTN sheets at scale 1:50,000 of the studied regions.

In Maps A-1 and A-2 (Figure 2), the three league circle made by the priest was made to coincide with a circle drawn on each current map of the same size. The latter was done using the UTM grid.

In Maps C-1 and C-2 (Figure 4), the graphic scale that appears at the bottom of the map of the region of Soria (Figure 1) was used.

After the maps were scaled, the towns (as points), roads and rivers (with line geometry) were digitalised. The final maps by Tomas Lopez provide considerably more information than the priests's maps, since it includes new elements such as bridges, caves, mountain ranges, shrines, mountains, and up to 33 new towns for the map of Chavaler and 15 for the map of Monteagudo. 


\section{Calculating the errors}

First, the linear and angular error for each town was calculated, followed by the median errors for maps $\mathrm{A}$ and $\mathrm{C}$ as a whole.

The distance in metres from Chavaler to each town was used to calculate the linear error of the towns, and it was compared with the benchmark map. The angular error was calculated the same way, taking the East direction which goes through Chavaler as the origin and the counter clockwise positive direction expressed in sexagesimal degrees (Figure 7). The same procedure is followed with Monteagudo.

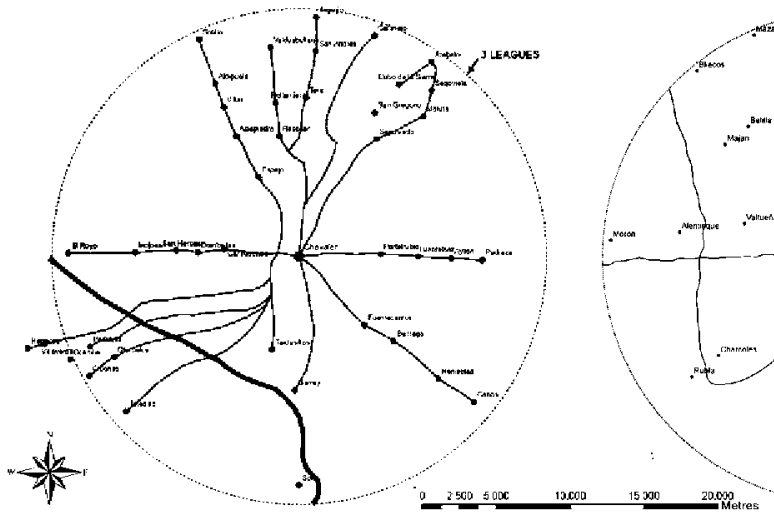

1) Chavaler region

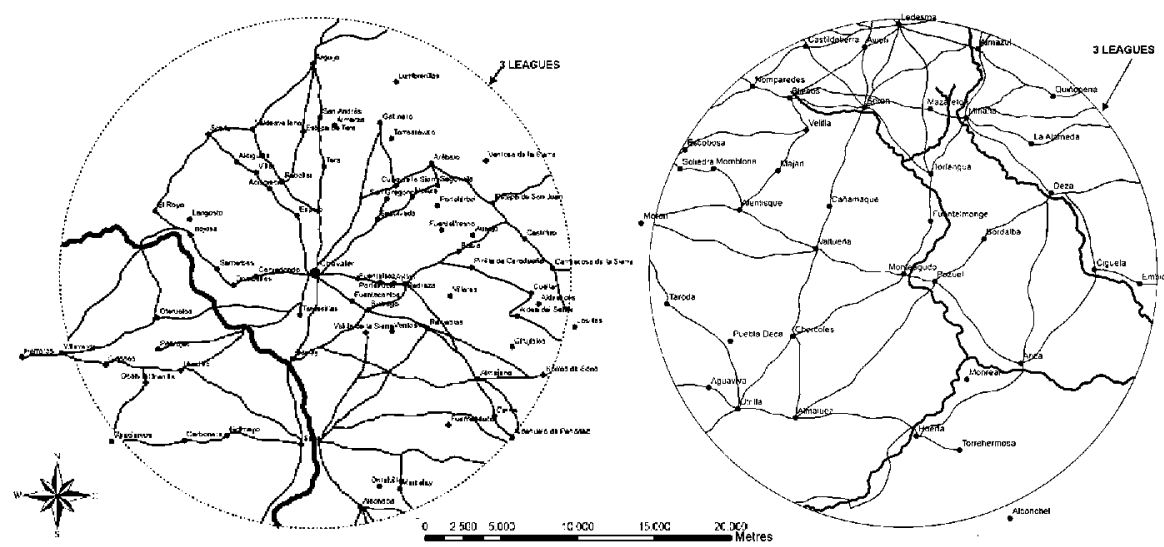

1) Chavaler region

2) Monteagudo region

Fig. 6. Maps C, digitalised. Likewise, the towns, roads and rivers are shown digitalised.

As an example of the method used to measure distances and angles to the two regions studied, in Figure 7 appear different distances and angles, according to the maps, among Chavaler and Cidones

Table 1 shows a statistic summary of the linear and angular errors for Chavaler's maps, the number of towns (n), minimum error (Min) and maximum error (Max), standard deviation (SD), and mean error $(\bar{e})$, of the towns shown on Map A (A-1) and Map C (C-1). Map C also makes a distinction between the 41 towns drawn by the priest and the 33 towns added by Tomas Lopez. 



Fig.7. Example of the measurement of distances and angles from the town of Chavaler to Cidones in maps A-1 and C-1 and the benchmark map (MTN).

Table 1: Statistics of village locations from Chavaler: Map A-1, Map C-1 vs. Map A, and Map C with villages added by Tomas Lopez

\begin{tabular}{|c|c|c|c|c|c|c|c|c|c|}
\hline \multirow{4}{*}{$\mathrm{n}$} & \multicolumn{6}{|c|}{ Linear error } & \multicolumn{3}{|c|}{ Angular error } \\
\hline & \multicolumn{2}{|c|}{ A-1 } & \multicolumn{4}{|c|}{ C-1 } & A-1 & \multicolumn{2}{|c|}{ C-1 } \\
\hline & \multicolumn{2}{|c|}{41} & \multicolumn{2}{|c|}{41} & \multicolumn{2}{|c|}{33} & 41 & 41 & 33 \\
\hline & (m) & $\%$ & (m) & $\%$ & (m) & $\%$ & $\left({ }^{0}\right)$ & $\left({ }^{\circ}\right)$ & $\left({ }^{\circ}\right)$ \\
\hline Min & 1 & 0 & 42 & 0 & 138 & 2 & 0 & 0 & 1 \\
\hline Max & 6762 & 121 & 4378 & 37 & 3554 & 35 & 38 & 43 & 35 \\
\hline SD & 1941 & 34 & 1039 & 9 & 856 & 9 & 10.6 & 11.2 & 8.1 \\
\hline Mean & 2933 & 43 & 1100 & 12 & 1403 & 13 & 15.7 & 15.2 & 15 \\
\hline
\end{tabular}

In view of the results, it could be said that as far as distance is concerned, Tomas Lopez's maps are rather inexact, despite the fact that he significantly improved the linear precision of the map sent by the priest by $62.5 \%$. Furthermore, the standard deviation (SD) shows that the errors are more dispersed in the priest's map. To be exact, he diminished the mean error by 1,833 metres. In regards to the angular error, which is also considerable in both maps, there is hardly any variation from one document to the other. The error committed by Tomas Lopez is only $0.5 \%$ less than the priest's error.

If we represent the linear error of the 41 towns on a chart according to their distances from Chavaler, we find that in most cases (in $75 \%$ of the towns) the errors in the priest's map exceed the errors found in Tomas Lopez's map.

On the other hand, when considering the towns added by Tomas Lopez, the mean errors have increased significantly, which confirms the fact that Lopez used the priest's maps to fit in his other sources of information.

In the same way, outlined in Table 2 a statistical summary of the linear and angular errors for Monteagudo's maps, differentiating for the 25 villages map C-2 also represented by the priest of the 14 added by Thomas Lopez.

Once again it is found that errors in distances of Tomas Lopez's maps are high. In the case of Monteagudo, the error means linear of cartographer is a little higher to the priest's. This is not verified in the case of angular errors that are smaller in Lopez's map. What is very significant is the increase of the linear error when considering only the villages whose appear on the map of Tomas Lopez and not the priest one. This error increases by $228 \%$, which demonstrates again that the main source of information for Tomas Lopez were maps of the priests.

\section{Study of the results}

Digitalization and measuring the distances and angles were done using ArcGIS software, which allows the definition of the attributes for each centre of population to 
be shown at the same time as they are drawn. The fact that certain alphanumeric information can be associated to spatial data allows us to analyse the results of the measurements in great detail.



Fig. 8. Linear error (in leagues) according to the distances to Chavaler on the priest's map and Tomas Lopez's map

Table 2: Statistics of Village locations from Monteagudo: Map A, Map C vs Map A, and Map C with added village by Tomás López

\begin{tabular}{|c|c|c|c|c|c|c|c|c|c|}
\hline \multirow{4}{*}{$\mathrm{n}$} & \multicolumn{6}{|c|}{ Linear error } & \multicolumn{3}{|c|}{ Angular error } \\
\hline & \multirow{2}{*}{\multicolumn{2}{|c|}{$\begin{array}{c}\text { A-2 } \\
25\end{array}$}} & \multicolumn{4}{|c|}{ C-2 } & \multirow{3}{*}{$\begin{array}{c}\text { A-2 } \\
25 \\
\left.\mathbf{C}^{\circ}\right)\end{array}$} & \multicolumn{2}{|c|}{ C-2 } \\
\hline & & & 2 & & & & & 25 & 14 \\
\hline & (m) & $\%$ & (m) & $\%$ & (m) & $\%$ & & $\left({ }^{\circ}\right)$ & $\left({ }^{0}\right)$ \\
\hline Min & 118 & 3 & 264 & 2 & 2165 & 15 & 1 & 1 & 0 \\
\hline Max & 5856 & 38 & 7926 & 42 & 9662 & 43 & 48 & 46 & 19 \\
\hline $\mathrm{SD}$ & 1734 & 10 & 1922 & 12 & 2331 & 8 & 13.7 & 12.3 & 19 \\
\hline Mean & 2906 & 20 & 2951 & 23 & 6731 & 30 & 18.8 & 12.1 & 7.2 \\
\hline
\end{tabular}



Fig. 9. Linear error (in leagues) according to the distances to Monteagudo on the priest's map and Tomas Lopez's map

For each one of the digitalised centres of population (Figure 8), their distance and angle in relation to Chavaler and Monteagudo were recorded as attributes associated to 
the spatial information, as well as their corresponding linear and angular errors. This allowed us to use the data to make consultations and to make theme maps.

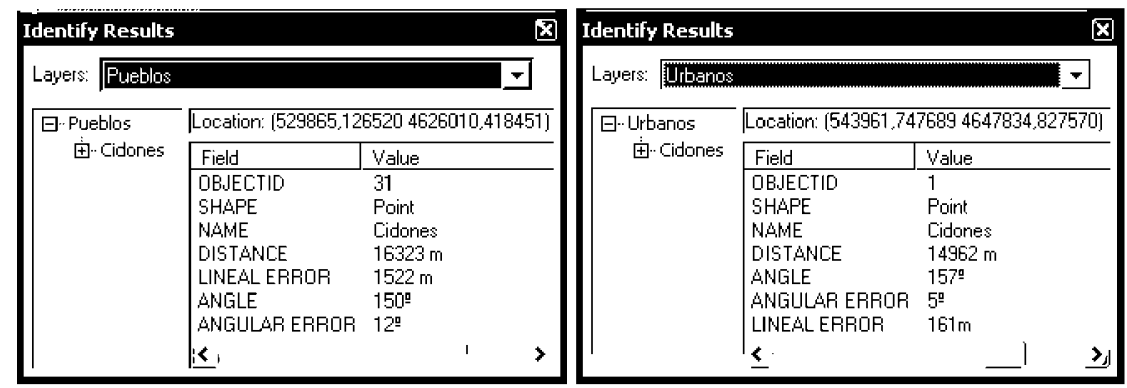

Fig. 10. Attributes associated to each digitalised (urban centre) town

As an example, Tomas Lopez's map (Figure 11) is depicted in such a way that the towns with a linear error of more than 1000 metres are drawn as squares, and towns that are below that figure are drawn as triangles. As can be seen, $54 \%$ of the towns have a linear error of more than 1000 metres.

However, if we use different distances to generate buffers around Chavaler, we find that the towns furthest away from Chavaler accumulate a higher linear error. In fact, $88 \%$ of the towns with a linear error in excess of $1000 \mathrm{~m}$ are more than $7500 \mathrm{~m}(1.3$ leagues) from Chavaler.

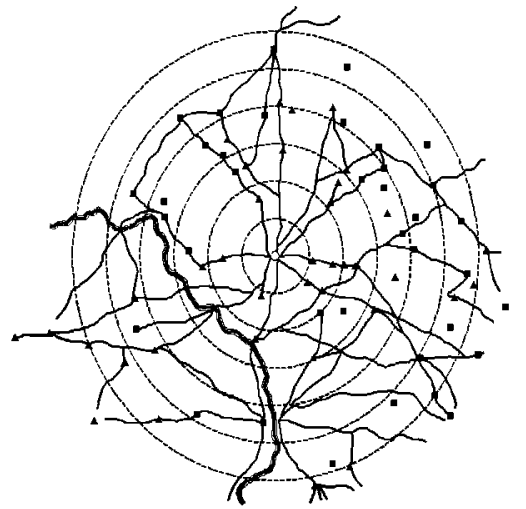

1) Chavaler

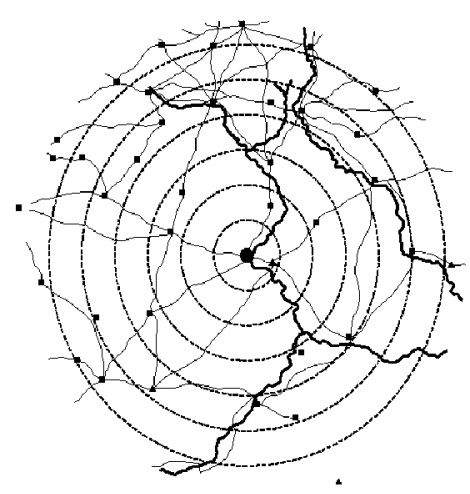

1) Monteagudo

Fig. 11. Map C: towns with more ( $\boldsymbol{-})$ and less ( $\mathbf{\Delta}$ ) than a linear error of $1000 \mathrm{~m}$ and buffers every $2500 \mathrm{~m}$

If we do the same analysis for Monteagudo, we note that the $87 \%$ of villages represented on the Tomas Lopez's map exceed $1000 \mathrm{~m}$ of linear error.

On the other hand, it can be seen in both the priests's maps and Lopez's maps that the relative position of certain towns in relation to others is more important than their exact position. For instance, on maps $A$ and $C$ show that to reach "El Royo" from Chavaler one had to go through "Canredondo", "Dombellas", "Santerbas" and "Inojosa". See (Figure 12) and (Figure 13).

Likewise, this manner of storing information allowed us to analyse the digitalisation of the Duero River. It is important to see how Tomas Lopez corrected the course of the river compared to the way it was drawn by the priest, thereby obtaining a path quite similar to the actual course (Figure 14). 


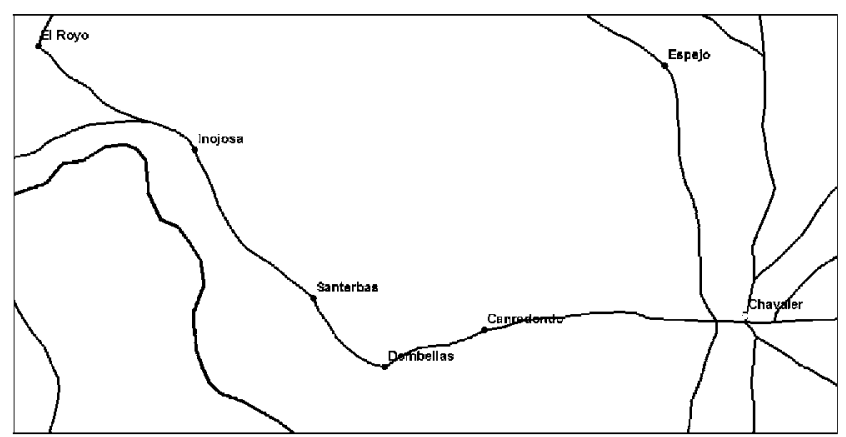

Fig. 12. From Chavaler to El Royo, according to Tomas Lopez



Fig. 13. From Chavaler to El Royo, according to the priest

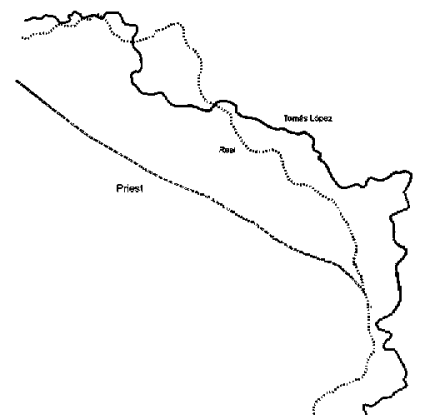

Fig. 14. The course of the Duero River on the priest's map and Tomas Lopez's map, and on the MTN 1:50.000 sheet

If we study the general treatment that makes Tomas Lopez of the information provided by the priests, and we represent on a system of Cartesian axes the distances of each village regarding their village origin, Chavaler and Monteagudo, which were measured on the maps of the priests and maps of Tomas Lopez, we Get linear regression showing that there is a ratio of 0.97 between the two distances.

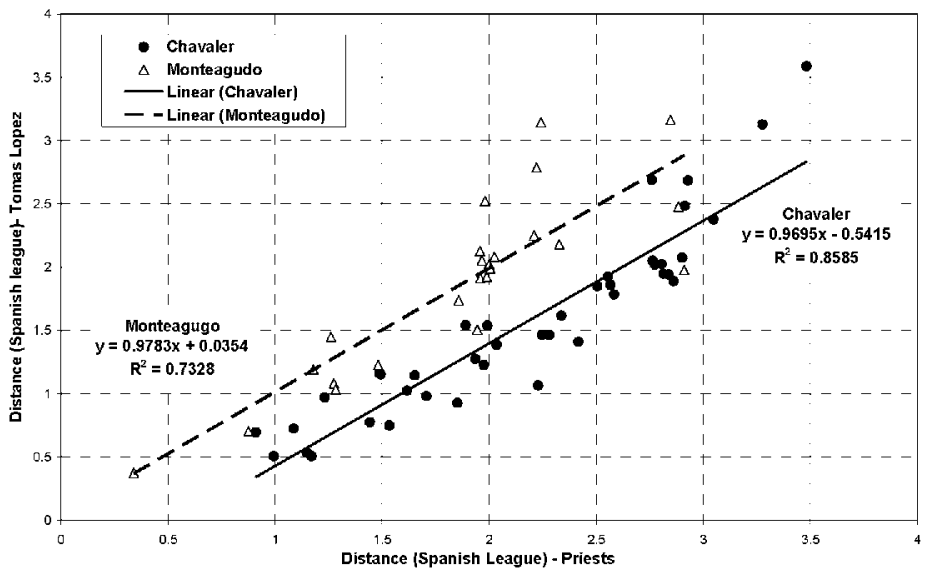

Fig. 15. Distances: Tomas Lopez vs Priests of Chavaler and Montagudo 
- The proposed methodology was found useful to study the linear and angular cartographic accuracy of historical maps in general, and Tomas Lopez's maps in particular.

- His work stands out for the enormous amount of information it gives. Tomas Lopez added 33 villages for Chavaler region and 14 for Monteagudo region, as well as other elements such as caves, bridges, mountain ranges, mountains, and shrines. This is because Lopez drew his maps from the sketches sent to him by village priests and from other graphic and written information that enabled him to complete his maps.

- When comparing Tomas Lopez maps of Chavaler and Monteagudo and its regions, located on the Map of Soria Province, with the benchmark cartography, it can be seen that:

o It is not very exact:

- Tomas Lopez's errors in distance are important $(1100 \mathrm{~m}$ and $2951 \mathrm{~m})$ despite the fact that in the case of Chavaler he corrected the mean linear error of the priest's sketch by $62.5 \%$, by using a distance summary provided by the province's quartermaster general.

- The distances errors for each town shown on Tomas Lopez's map increases as they are further away from the benchmark towns, that is, Chavaler and Monteagudo, and they are very high after 1.3 Spanish leagues.

- As for the angles, the error is also important. The priests knew whether a town was more or less in line and linked to others, but not its exact angular position in relation to the benchmark town. These errors in orientation appear in the same way in Tomas Lopez's final map.

- The priests' maps were very valuable for a cartographer. The errors in distance of the towns added by Tomas Lopez in his final map are higher than the errors for the towns depicted by the priest.

- The metric errors made by Tomas Lopez in the cases we have studied were due to the cartographic method he used, based solely on desk work and very imprecise information, such as the priests' sketches and maps, which were not verified in the field by surveying methods. He compared the sketches and maps with each other and searched for the exact location on the basis of a number of astronomic positions which were known for certain at the time. In any case, Tomas Lopez attempted to make as detailed a graphic inventory as possible. He showed more interest in the topological relationship between the elements on the map than in their accuracy.

- $\quad$ Finally, in view of the results obtained, one might ask if Tomas Lopez had methodically applied a factor downscaling $(0.97)$ to maps of the priests, similar to the modern cartography, such as factor downsizing of the UTM projection (0.9996).

\section{ACKNOWLEDGEMENTS}

Our sincere acknowledgements to the Biblioteca Nacional de España for Figures 1, 2, 3 and 4 . 


\section{References}

1. Alinhac, G., 1973. Historique de la Cartographie. Ed. Eyrolles, Paris.

2. Berthaut, C., 1902. Les Ingeniers Géographes Militaires 1624-1831. T. II. Service Geographique de l'Armée, Paris, pp. 177-198.

3. Buschings, A. F., 1976. Genauere Bechreibung der Lopezischen Charten von Spanien. Bochentliche Nachrichten von neuen Landcharten, geographischen Buchern un Sachen, Berlin $4^{\circ}$ apéndice, $37^{\mathrm{a}}$ parte, 9 Septiembre. Pág. 298-391.

4. Chevalier M., 1707. Sur la Manière de lever la carte d'un pays. Histoire de L'Academie Royal de Sciences. París. pp. 113 - 116.

5. Clark, P. K., Jones, Y., 1974. British military map making in the Peninsular war. ICA. International Cartographic Association. VII Conferencia Internacional de Cartografía, Madrid, p. 106.

6. Hernando, A. 2005. El Atlas Geográfico de España (1804) producido por Tomás López. Instituto Geográfico Nacional. Centro Nacional de Información Geográfica, Madrid, 284 pages.

7. León Casas, M. Á., 2001. El Sistema de Planos Acotados: Historia de un convencionalismo gráfico y su aplicación en el ámbito de la ingeniería civil, Universidad de Granada, Granada.

8. Liter Mayayo, C., 2001. Tesoros de la cartografía española. Biblioteca Nacional, Madrid, p. 112.

9. Liter Mayayo, C., 2002. La obra de Tomás López. Imagen cartográfica del siglo XVIII. Biblioteca Nacional, Madrid, p. 14.

10. López Gomez, A., Manso Porto, C., 2006. Cartografia del Siglo XVIII. Tomás López en la Real Academia de la Historia. Ed. Real Academia de la Historia, Madrid, 588 pages, p. $155-243$.

11. López, T., 1804. Atlas Geografico de España que comprehende el mapa general del Reyno y los particulares de sus Provincias. Two copies are kept at the Biblioteca Nacional de España, under catalogue numbers GM/300g and GM/1190g. They have 102 sheets which contain 38 maps, engraved in copper. Their scales vary between $1: 100.000$ and $1: 650.000$.

12. Manzano Agugliaro, F.; Manzano Agugliaro, G.; San-Antonio Gómez, C., 2005. El levantamiento topográfico y la cartografía en el siglo XVIII: el método de la topografía eclesiástica. Actas del Congreso y CD del XVII INGEGRAF - XV ADM. Congreso Internacional de Ingeniería Gráfica. Sevilla (España).

13. Núñez de las Cuevas, R., 1991. Historia de la Cartografía española. La cartografía de la Peninsula Ibérica y la seva extensió al continent Americà, Institut Cartográfic de Catalunya, Barcelona, p. 190.

14. Núñez de las Cuevas, R., 1991. Historia de la Cartografía española, La cartografía de la Península Ibérica y la seva extensió al continent Americà, Institut Cartográfic de Catalunya, Barcelona, p. 200.

15. Olarán Múgica, C., 2004. Índice de las Relaciones Geográficas enviadas a Tomás López, Biblioteca Nacional, Madrid, pp. 13-14.

16. Pouls, H.C., 1989. The trigonometry of triangulation. Caert-Thresoor, 8, (3): 61-71.

17. Romans M., 2006. Drawing their own conclusions: British topographical reconnaissance in the Peninsular War. Wellington Congress, 2006: abstracts of papers, University of Southampton.

18. Sáez García, J. A., 2004. Gipuzkoa en el siglo XVIII a la luz de la obra de Tomás López. INGEBA, San Sebastián, p.250.

19. Sanz Hermida, J. M., 1992. Estudio cartográfico del Atlas Geographico de España, e islas adyacentes de Thomás López. Edición Facsimil del Atlas de Tomás López. Europa Ediciones de Arte, Salamanca.

20. Torge W., 1980. Geodesy. $2^{\text {nd }}$ Edition. Gruyter, Berlin-Ney York. p. 4.

21. Vayssiére, B.H. 1980. Cartes minimales. Des cartes en Espagne. Cartes et Figures de la terre. Centre Georges Pompidou, Paris, pp. 167-177. 